\title{
Selective herbivory by amphipods inhabiting the brown alga Zonaria angustata
}

\author{
Alistair G. B. Poore* \\ Department of Ecology and Evolutionary Biology, Monash University, Clayton, Victoria 3168, Australia
}

\begin{abstract}
The feeding preferences of small, invertebrate herbivores inhabiting the brown alga Zonaria angustata were examined. The 2 most common herbivores, the amphipods Tethygeneia sp. and Hyale rubra, consumed $Z$. angustata, strongly preferring the meristematic region at the apex of each branch. Amphipod preference for new growth and the extent of damage to plants in the field suggest that they may cause considerable damage to $Z$. angustata. In contrast to the common preconceptions about the diets of such herbivores, amphipods did not consistently prefer to consume the most abundant epiphytes of $Z$. angustata ahead of the host macroalga itself. $Z$. angustata was not a homogeneous food source for amphipods. Amphipod feeding was negatively correlated with the density of phlorotannin-containing physodes in, but not with toughness of, the tissues at the apex of each branch. This correlation indicated that the pattern of damage to $Z$. angustata was most likely a result of within-plant variation in the amount of secondary chemicals. This variation occurred over only a few millimetres but influenced amphipod feeding due to their ability to select between algal tissues at a very small scale.
\end{abstract}

KEY WORDS: Herbivory · Amphipods - Algae - Feeding preference

\section{INTRODUCTION}

Marine macroalgae are commonly associated with a diverse assemblage of small invertebrates, many of which are herbivores and potentially consume their host plants. Collectively referred to as 'mesograzers' (Hay et al. 1987), these small herbivores include amphipods (e.g. Duffy 1990), isopods (e.g. Arrontes 1990), small crabs (e.g. Coen 1988), polychaetes (Fauchald \& Jumars 1979), dipteran larvae (e.g. Robles \& Cubit 1981), shrimps and small molluscs (Brawley 1992). Studies of marine herbivory have focused primarily on large and conspicuous herbivores: fish and urchins in tropical regions, and gastropods and urchins in temperate regions. Despite their high abundance, often in the order of thousands per square metre of substratum, the way in which small, mobile herbivores affect algae is poorly understood (Brawley 1992).

- Present address: School of Biological Science, University of New South Wales, PO Box 1. Kensington, NSW 2033, Australia
Mesograzers inhabiting macroalgae have the opportunity to feed not only on their host plant but also on a wide variety of epiphytes that commonly foul macroalgae (D'Antonio 1985, Wahl 1989). Epiphytes are usually detrimental to the host, with negative effects including shading, decreased carbon uptake, competition for nutrients, increased drag and the risk of damage by large herbivores of the epiphytes (Sand-Jensen 1977, D'Antonio 1985, Wahl 1989). The feeding preferences displayed by mesograzers between the host and its epiphytes therefore have great significance for host plant fitness. Mesograzers may affect their host indirectly through removal of epiphytes, or directly through consumption of host plant tissue. Numerous studies have shown that mesograzers have the ability to reduce the epiphyte loads of algae, potentially benefiting their host (e.g. D'Antonio 1985, Brawley \& Fei 1987, Duffy 1990).

The feeding preference of mesograzers has also been of interest recently due to the hypothesis of Hay et al. (1987) regarding the interaction between small marine herbivores and algal chemical defences. In 
common with terrestrial plants, algae contain a wide variety of secondary metabolites, many of which act as herbivore deterrents. These include terpenes, aromatic compounds, acetogenins, amino-acid-derived substances and polyphenolic compounds (Hay \& Fenical 1988). Polyphenolic compounds, known as phlorotannins, are found only in the brown algae and are localised within highly refractive subcellular bodies termed physodes (Ragan \& Glombitza 1986). Hay et al. (1987) argued that amphipods that both feed and live on their host plants may experience lower levels of predation by consuming algae that are chemically defended against omnivorous or herbivorous fish. It was suggested that the relationship between mesograzers and the algae they inhabit may be similar to that of insects and terrestrial plants, with host plant choice often influenced by predation. This and later studies on amphipods, polychaetes, crabs and ascoglossan gastropods demonstrated similar patterns, in which small herbivores are resistant to chemical defences that effectively deter larger herbivores (reviewed in Hay \& Fenical 1992, Hay \& Steinberg 1992).

Bell (1991) criticised Hay et al.'s (1987) hypothesis, arguing that amphipods rarely eat macroalgae in the field, preferring to feed upon small epiphytes. She also argued that because amphipods are seldom specialist herbivores, and may feed from a variety of epiphytes while living on a single host plant, a strong relationship between amphipod feeding preference and algal secondary chemistry is unlikely (but see reply by Duffy \& Hay 1991a). Bell (1991) suggested that the 'amphipod-epiphyte linkage ... deserves critical attention because small epiphytic plants on macroalgae may be the more appropriate scale over which to judge feeding preferences'.

This study investigated the feeding preferences of mesograzers inhabiting Zonaria angustata (Kützing) Papenfuss (Phaeophyta: Dictyotales) on the small scale suggested by Bell (1991). The potential impact of the 2 most common mesograzers, the gammaridean amphipods Hyale rubra (Thomson) and Tethygeneja sp., on $Z$. angustata was investigated by determining their feeding preferences between different parts of their host plant, and between their host plant and its epiphytes. Within-plant preference was examined because preliminary observations indicated that amphipod feeding was not evenly distributed on $Z$. angustata. Most studies of marine herbivory have treated algae as a homogeneous food source for herbivores, and have not considered the importance of withinplant variation. Possible reasons for within-plant feeding preference were examined by recording the distribution of physodes and toughness in different tissues of $Z$. angustata.

\section{MATERIALS AND METHODS}

Study site and organism. Zonaria angustata and its associated invertebrates were collected from deep rock pools and the shallow subtidal region at Barwon Heads, Victoria, Australia $\left(38^{\circ} 17^{\prime} \mathrm{S}, 144^{\circ} 30^{\prime} \mathrm{E}\right)$. This species has many branches, 2 to $5 \mathrm{~mm}$ wide and up to $15 \mathrm{~cm}$ in length, and is common on exposed and moderately exposed coasts in southeastern Australia (Womersley 1987). It often supports heavy epiphyte loads. The secondary compounds of algae in the order Dictyotales are well known and a diverse collection, including terpenoids, acetogenins, alkylated phenolics and $\mathrm{C}_{11}$ hydrocarbons, in addition to the phlorotannins present in most brown algae, has been isolated (Faulkner 1984). In the only study of the secondary chemistry of $Z$. angustata, Blackman et al. (1988) reported the presence of a phloroglucinol derivative identical to that found in northern hemisphere species of Zonaria (Gerwick \& Fenical 1982).

Species composition of invertebrate fauna. The most common potential herbivores inhabiting Zonaria angustata were identified for use in feeding preference experiments by an initial description of the invertebrate fauna associated with this alga. The entire invertebrate fauna associated with 5 plants from Barwon Heads was sampled on 16 March 1992. The plants were quickly enclosed underwater in fine mesh bags, sealed and brought to the surface. In the laboratory, the invertebrates were removed from the algae by three 1 min immersions in fresh water separated by 1 min periods in seawater, as described in Holmlund et al. (1990). All invertebrates retained on a $500 \mu \mathrm{m}$ sieve were collected. The algae were examined carefully under a dissecting microscope for invertebrates not removed by the freshwater technique.

Feeding preference experiments. Amphipods were tested for feeding preference within different parts of Zonaria angustata, and between $Z$. angustata and 5 of its commonest epiphytes. Feeding preference experiments between 2 food types were designed and analysed according to Peterson \& Renaud (1989) with modifications to allow for the simultaneous testing of 2 consumer species. I adopted their definition of feeding preference, with preference being 'measured by quantitative comparison of amounts eaten' given that the consumer has a choice between food types.

Each experimental unit consisted of a choice of 2 pieces of algae in a $50 \mathrm{ml}$ plastic container filled with seawater. Each algal piece was initially blotted dry on tissue paper and its wet mass recorded to $0.1 \mathrm{mg}$. The experimental units were assigned haphazardly to 3 treatments, with 20 replicate containers for each treatment. The treatments were: addition of 1 individual of Tethygeneia sp., addition of 1 individual of Hyale 
rubra, and a control without amphipods. The units were placed on trays in a controlled temperature room at $16^{\circ} \mathrm{C}$ under a $10.5 \mathrm{~h}$ light: $13.5 \mathrm{~h}$ dark cycle. After $24 \mathrm{~h}$ the algal pieces were blotted dry and reweighed.

Large amphipods were used to ensure that the amount of algae consumed could be recorded by mass changes. Animals were used singly to avoid any behavioural interactions that may influence feeding preference. Feeding in the laboratory was not continuous and amphipods were starved for $24 \mathrm{~h}$ prior to the start of the experiment to minimise the number of amphipods that did not feed. The experiments were run for only $24 \mathrm{~h}$ to prevent either of the food types from being totally consumed and to minimise changes in mass not due to herbivory. In all cases the algal pieces were free of visible epiphytes and brushed clean of detritus.

For each experimental unit the value recorded for analysis was the difference in mass change between the 2 food types (Peterson \& Renaud 1989). This method accounts for the possibility that change in mass not due to herbivory (i.e. growth or decay) may differ between the 2 food types. The difference in mass loss between the 2 food types was analysed using ANOVA with the 2 experimental treatments and the control being 3 levels of 1 factor. Two planned comparisons, which indicated whether each amphipod species had displayed a feeding preference, were conducted for each experiment: that between the levels Tethygeneia sp. and control, and that between the levels Hyale rubra and control. The uninformative cases in which the amphipod died, consumed no algae, or consumed all of both types, were excluded from the analysis.

The within-plant preference experiment consisted of the choice between new growth from the apical region of Zonaria angustata cut from each branch approximately $3 \mathrm{~mm}$ from the apex, and visibly paler than the tissue below, and older growth cut from below this region. The 5 epiphyte taxa, subjectively judged most abundant, were Ulva rigida C. Agardh, Colpomenia peregrina (Sauvageau) Hamel, Chaetomorpha coliformis (Montagne) Kützing, Corallina officinalis Linnaeus and encrusting Corallinaceae. All preference experiments, except those conducted with $C$. coliformis, used cut algal pieces approximately $3 \mathrm{~mm}$ in length and matched for area to ensure that each food type was encountered with equal probability. Small plants of $C$. coliformis were used whole and matched for wet weight with the $Z$. angustata pieces since it was not possible to match pieces for area. Very small individuals of all the epiphyte taxa, aproximating the size of the pieces used in the feeding experiments, were present on $Z$. angustata in the field.

Amphipod feeding in the field. The gut contents of Tethygeneia sp. and Hyale rubra collected from
Zonaria angustata in the field were examined. Gut contents were dissected from animals fixed in formalin and placed onto slides for inspection under the compound microscope. To aid the identification of $Z$. angustata in the guts of amphipods, both Tethygeneia sp. and $H$. rubra were fed exclusively on this alga for $3 \mathrm{~d}$ in the laboratory, and their guts examined.

Ten plants, haphazardly collected from several rock pools on 18 September 1992, were examined under the dissecting microscope to estimate the extent of herbivore damage to Zonaria angustata in the field. On each plant, the proportion of all actively growing branches that displayed damage to their apices consistent with that of amphipod feeding in the laboratory was recorded

Distribution of physodes and toughness in branch apices. The strong preference displayed by the amphipods for the new growth of Zonaria angustata could be explained by greater chemical or mechanical defence of the older growth. To test the first hypothesis, the pattern of damage by amphipods was compared with the distribution of physodes within the meristematic region of $Z$. angustata. The distribution of physodes was determined by light microscopy of hand sections from several plants, and from photomicrographs of a prepared section. The apical region was fixed in $2 \%$ glutaraldehyde, $2 \%$ paraformaldehyde and $1 \%$ caffeine in a seawater buffer $(0.1 \mathrm{M}$ sodium cacodylate and $0.25 \mathrm{M}$ sucrose). The tissue was postfixed in osmium tetroxide for $2 \mathrm{~h}$ after being washed in the buffer with decreasing concentrations of sucrose. The tissue was embedded in Spurr's resin after dehydration using acetone of increasing concentration (10\% steps) with 3 changes at $100 \%$. Longitudinal sections $2 \mu \mathrm{m}$ thick were taken through the apical region with a Reichert Ultracut microtome. Physodes were distinguished by their dark-staining reaction with $\mathrm{OsO}_{4}$ (Ragan \& Glombitza 1986).

Branch toughness of new and old growth were compared using a Chatillon automatic force recorder (model UTSE-2). Two sharpened metal blocks were driven past each other at a constant rate, cutting the algal branch cleanly. As the branch is cut, the force required and the distance moved by the block is recorded 15 times a second. From this information a force versus distance plot is obtained, with the maximum force required to break the alga being the difference between the force when the blocks first contact the alga and the force when the alga breaks. Nine replicate recordings were taken for both new and old growth, using separate branches from the same plant for each recording

Statistical procedures. Data analyses were carried out using SYSTAT (Wilkinson 1990). For ANOVA, the assumptions of normality and homogeneity of variance 
were checked using box plots and plots of residuals versus means, respectively. Square root, logarithm or reflected transformations were made where appropriate (Tabachnick \& Fidell 1989). The influence of outliers was checked by repeating the analysis after their removal. The significance level was taken as $p<0.05$.

\section{RESULTS}

\section{Species composition of invertebrate fauna}

A species-rich and abundant invertebrate fauna was associated with Zonaria angustata. A total of 1780 individuals, comprising 81 species from 11 animal phyla, was collected from 5 plants of $Z$. angustata. Up to 50 species and 450 individuals were found on single plants. The fauna was dominated numerically by gammaridean amphipods, harpacticoid copepods, gastropods and polychaetes.

The invertebrate fauna included several potential herbivores of Zonaria angustata. These were gammandean and caprellid amphipods, sphaeromatid isopods, nereid polychaetes, shrimps, trochid gastropods and dipteran larvae. In addition to those collected in the initial sampling process, idoteid isopods and the majid crabs were encountered regularly in small numbers from later collections.

The mesograzers chosen for the feeding preference experiments were the gammaridean amphipods Tethygeneia sp. and Hyale rubra, the 2 most abundant mesograzers inhabiting Zonaria angustata. Tethygeneia $\mathrm{sp}$. was the most abundant invertebrate collected and individuals of this species comprised $33 \%$ of all potential herbivores. H. rubra comprised $17 \%$ of potential herbivores.

\section{Feeding preference experiments}

Both Tethygeneia sp. and Hyale rubra readily fed on Zonaria angustata in the laboratory, but their feeding was almost entirely confined to the region of new growth just below and including the apical meristem. A sharp boundary was always present between the region eaten and that avoided by the amphipods and the single row of apical meristematic cells was also often avoided (Fig. 1). In the feeding preference experiments, Tethygeneia sp. and $H$. rubra both preferred new growth to old (Fig. 2a, Table 1). On rare occasions the old growth was eaten, mainly by large specimens of $H$. rubra. H. rubra was also observed to eat senescent tissue and the rhizoids that make up the holdfast in $Z$. angustata. Both amphipods readily ate decomposing tissue of $Z$. angustata.

Zonaria angustata often supported a dense cover of epiphytes. Of the 5 epiphytes used in the feeding preference experiments, the amphipods readily ate Ulva rigida, Colpomenia peregrina and Chaetomorpha coliformis, but did not consume either of the coralline red algae. Both Tethygeneia sp. and Hyale rubra preferred the new growth of $Z$. angustata to the epiphytic U. rigida (Fig. 2b, Table 1). C. peregrina was preferred to $Z$. angustata by both amphipods (Fig. 2c, Table 1). Amphipods, however, were not observed to eat intact plants of $C$. peregrina. Cutting the alga into squares, in order to offer the amphipods the same area as that of $Z$. angustata in the preference experiment, facilitated feeding by amphipods. No feeding preference between $Z$. angustata and $C$. coliformis was detected for either amphipod (Fig. 2d, Table 1). It was not possible through transformations to achieve homogeneity of variance for the data set collected from the $C$. coliformis preference experiment. However, since the violation of this as-

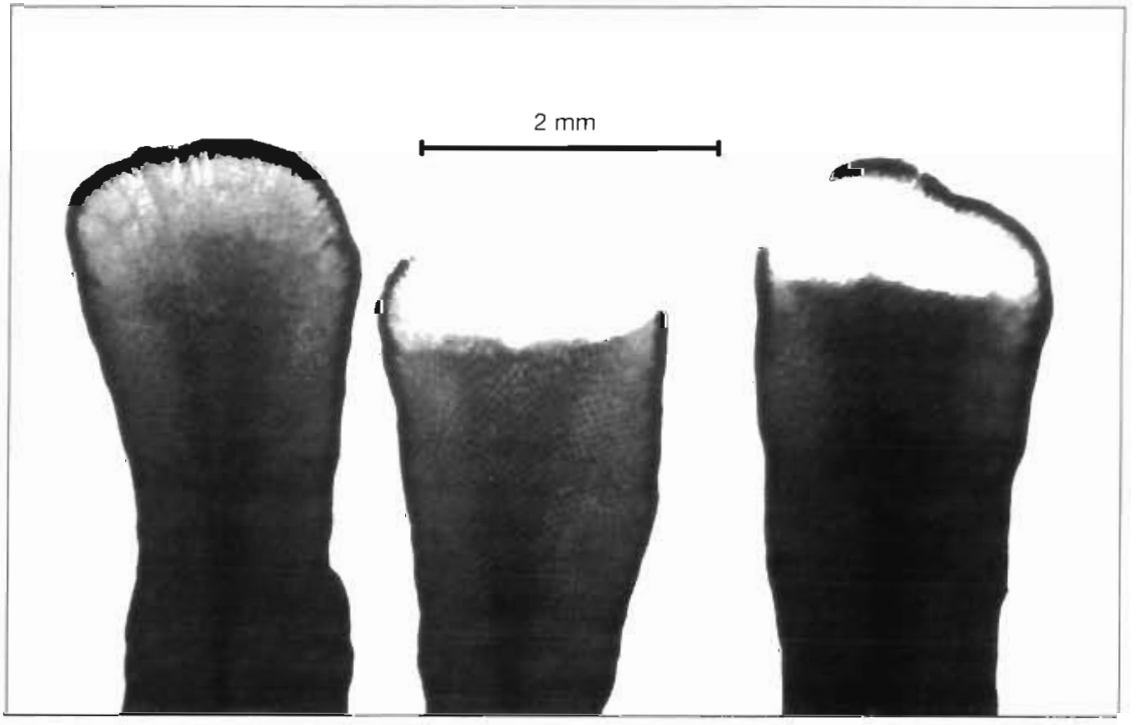

Fig. 1. Apical region of Zonaria angustata branches: intact (left) and displaying the damage as a result of feeding by Hyale rubra (centre and right) Feeding by Tethygeneia sp. resulted in the same pattern of damage 
a $Z$. angustata - new vs old growth

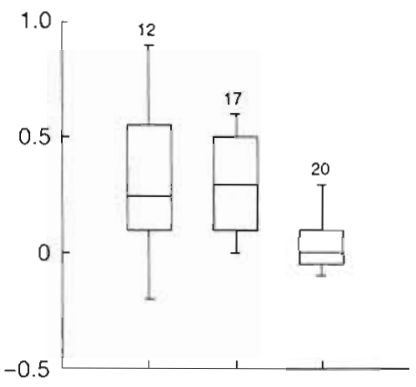

d $Z$. angustata vs $C$. coliformis
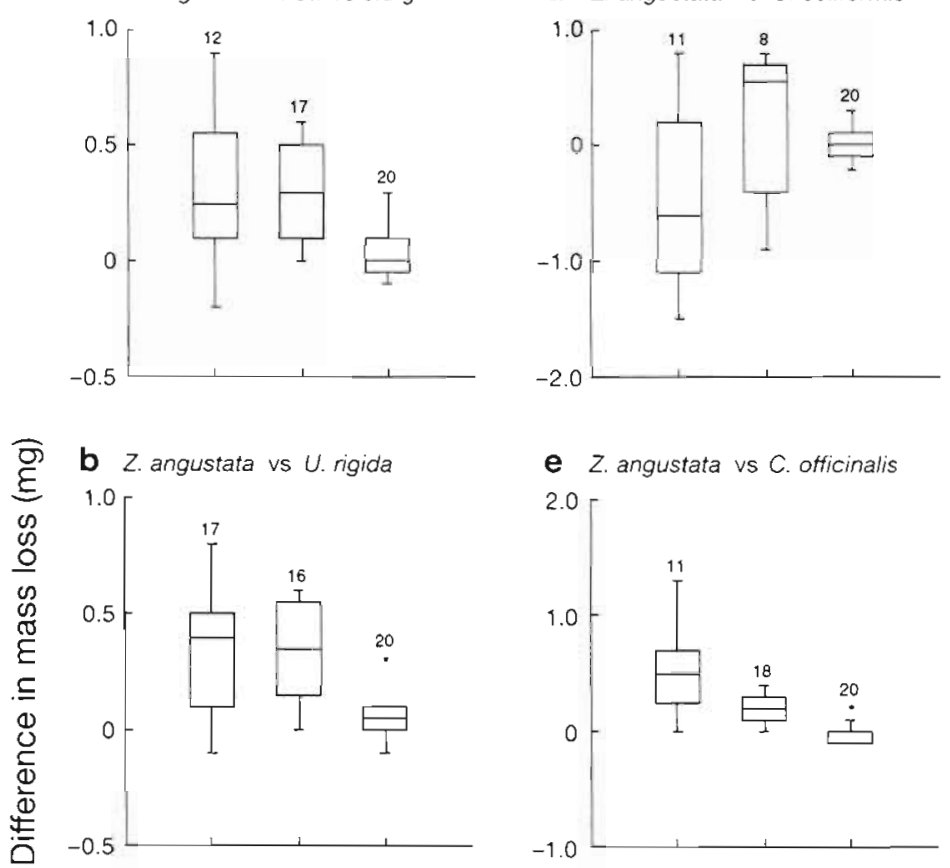

C Z. angustata vs C. peregrina

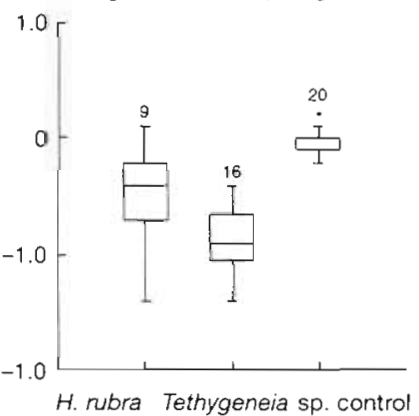

e Z. angustata vs C. officinalis 2.0

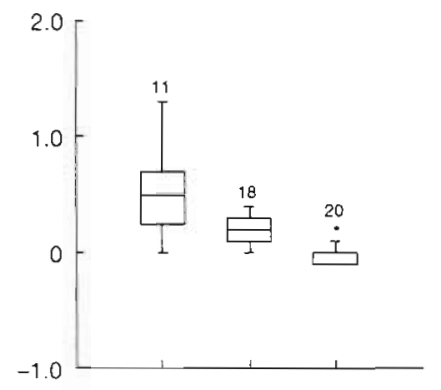

$f \quad$ Z. angustata vs encrusting Corallinaceae

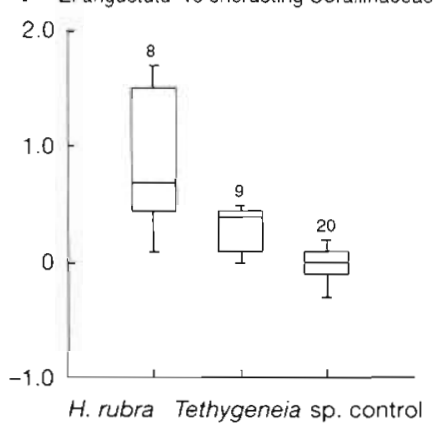

Fig. 2. Box plots of the difference in mass loss between 2 food types in the feeding preference experiments. (a) Zonaria angustata new vs old growth; (b to f) $Z$. angustata vs epiphytes. Difference in mass loss is (a) mass loss in new growth minus old; and ( $b$ to f) mass loss in $Z$. angustata minus mass loss in epiphyte. Horizontal lines in each box plot are, from top to bottom: maximum, third quartile, median, first quartile and minimum. Outliers. The number above each box plot denotes sample size. Additional replicates, that would make the total for each treatment 20 , were excluded from the analysis when the amphipods died, consumed no algae, or consumed all of both pieces of algae

sumption does not affect the reliability of a nonsignificant result (Underwood 1981), it was safe to conclude that there was no preference. Obviously, Tethygeneia sp. and H. rubra preferred Z. angustata to both Corallina officinalis and encrusting Corallinaceae because these algae were not consumed (Fig. 2e, f, Table 1).

Amphipod mortality in all preference experiments was very low, with only 9 amphipods dying from a total of 240 used.

\section{Amphipod feeding in the field}

The gut contents of Tethygeneia sp. and Hyale rubra fed exclusively on Zonaria angustata in the laboratory consisted largely of brown, unidentifiable material with few intact algal cells present. The guts of $H$. rubra collected from $Z$. angustata in the field contained similar brown material with some macroalgal cells, including those of $Z$. angustata, and filamentous algae present. No intact cells were isolated from the gut contents of Tethygeneia sp.

Damage consistent with that of amphipods in the laboratory was evident from plants of Zonaria angustata in the field. Individual plants of $Z$. angustata had between 2.5 and $10.7 \%$ of all actively growing branches damaged, with a mean $( \pm S D)$ of $6.1 \pm 2.8 \%(n=10)$. Individual plants had a mean $( \pm \mathrm{SD})$ of $1279 \pm$ 822 actively growing branches $(n=10)$.

\section{Distribution of physodes and toughness in branch apices}

Amphipod feeding on the tissues of the apical region of Zonaria angustata branches was negatively correlated with the presence of physodes. The apical cells, often avoided by amphipods, have very dense deposits of physodes (Fig. 3). The subapical cells, strongly preferred by amphipods, have few physodes, and those present are concentrated in the cortical cells. Further from the meristem, the region avoided by amphipods has many physodes in both the cortical and medullary cells.

The mean $( \pm \mathrm{SD}$ ) maximum force required to cut the new growth was $1.05 \pm 0.61 \mathrm{~N}$. This did not differ significantly from the mean $( \pm \mathrm{SD}$ ) of $0.82 \pm 0.55 \mathrm{~N}$ required to cut the old growth close to the apex $(t=-0.890, \mathrm{p}=0.39$, $\mathrm{df}=16, \log$ transformed data).

\section{DISCUSSION}

\section{Amphipod feeding preferences}

The amphipods Tethygeneia sp. and Hyale rubra readily consumed their macroalgal host in the laboratory. Species of Hyale are common members of the invertebrate assemblages inhabiting macroalgae worldwide (Moore 1977, Buschmann 1990), and they are 
Table 1. ANOVA of feeding preference experiments. The experimental factor amphipod has 3 levels: addition of Tethygeneia sp., addition of Hyale rubra, and a control with no amphipod. The diifference in mass loss between the 2 algal types was analysed with planned comparisons between each amphipod and the control. Data (a) square root transformed (b, e, f) log transformed or (c, d) reflected then log transformed

\begin{tabular}{|c|c|c|c|c|c|}
\hline Preference experiment & Source & $\mathrm{df}$ & MS & $F$ & $\mathrm{p}$ \\
\hline \multirow[t]{4}{*}{ (a) $Z$. angustata: new vs old growth } & Amphipod & 2 & 0.134 & 8.911 & 0.001 \\
\hline & Tethygeneia sp. vs control & 1 & 0.196 & 13.018 & 0.001 \\
\hline & H. rubra vs control & 1 & 0.183 & 12.194 & 0.001 \\
\hline & Error & 46 & 0.015 & & \\
\hline \multirow[t]{4}{*}{ (b) Z. angustata vs Ulva rigida } & Amphipod & 2 & 0.192 & 13.305 & $<0.001$ \\
\hline & Tethygeneia sp. vs control & 1 & 0.275 & 19.064 & $<0.001$ \\
\hline & H. rubra vs control & 1 & 0.282 & 19.568 & $<0.001$ \\
\hline & Error & 50 & 0.014 & & \\
\hline \multirow[t]{4}{*}{ (c) Z. angustata vs Colpomenia peregrina } & Amphipod & 2 & 1.177 & 47.711 & $<0.001$ \\
\hline & Tethygeneia sp. vs control & 1 & 2.338 & 94.767 & $<0.001$ \\
\hline & H. rubra vs control & 1 & 0.471 & 19.069 & $<0.001$ \\
\hline & Error & 42 & 0.025 & & \\
\hline \multirow[t]{4}{*}{ (d) Z. angustata vs Chaetomorpha coliformis } & Amphipod & 2 & 0.057 & 3.969 & 0.028 \\
\hline & Tethygeneia sp. vs control & 1 & 0.037 & 2.558 & 0.116 \\
\hline & H. rubra vs control & 1 & 0.041 & 2.824 & 0.102 \\
\hline & Error & 36 & 0.014 & & \\
\hline \multirow[t]{4}{*}{ (e) Z. angustata vs Corallina officinalis } & Amphipod & 2 & 0.301 & 34.471 & $<0.001$ \\
\hline & Tethygeneia sp. vs control & 1 & 0.198 & 22.634 & $<0.001$ \\
\hline & H. rubra vs control & 1 & 0.582 & 66.543 & $<0.001$ \\
\hline & Error & 46 & 0.009 & & \\
\hline \multirow[t]{4}{*}{ (f) $Z$. angustata vs encrusting Corallinaceae } & Amphipod & 2 & 0.568 & 26.941 & $<0.001$ \\
\hline & Tethygeneia sp. vs control & 1 & 0.239 & 11.314 & 0.002 \\
\hline & H. rubra vs control & 1 & 1.091 & 51.748 & $<0.001$ \\
\hline & Error & 32 & 0.021 & & \\
\hline
\end{tabular}

primarily herbivores of living algae (e.g. Moore 1977 McGrouther 1983, Hay et al. 1988a). Other amphipods in the family Hyalidae are important detritivores in a variety of habitats (Wildish 1988). The feeding ecology of Tethygeneia, a common genus inhabiting the algae of southern Australia (Edgar 1983), has not previously been studied although Edgar (1992) believed that a species in Western Australian seagrass beds fed largely on decaying plant matter. Pontogeneia rostrata, also in the family Eusiridae, feeds on ephemeral and epiphytic algae (Brawley \& Fei 1987).

The effect of herbivores on plants is not a simple function of the amount of tissue consumed because plant parts do not contribute equally to plant fitness (Rhoades 1979). The amphipods strongly preferred the meristematic region at the apex of each branch of
Zonaria angustata. This indicates that Tethygeneia sp. and Hyale rubra have the potential to affect their host greatly without consuming large amounts of tissue because the loss of meristematic tissue is more damaging than loss of an equivalent amount of nonmeristematic tissue.

Damage to the apical region of Zonaria angustata branches, consistent with amphipod feeding, was evident in the field and the proportion of branches damaged indicates that amphipods may be important herbivores of this alga. Tethygeneia sp. and Hyale rubra, however, do not appear to be specialised to feed on and inhabit $Z$. angustata as they were collected from a wide variety of macroalgae. Meristems were observed to regenerate on damaged branches, and therefore the impact of herbivores will depend on the time taken for

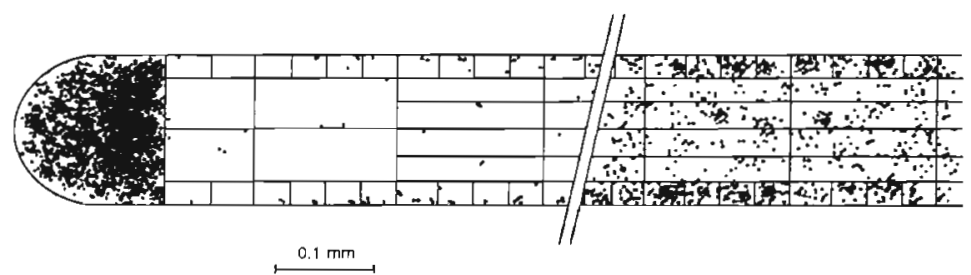

Fig. 3. Distribution of physodes in a longitudinal section of the apical tissues of Zonaria angustata. Physode distribution was compiled from photomicrographs. Physodes are visible as dark-staining subcellular bodies with high densities in the apical meristem cell (left) and old growth (right), and low densities in the new growth adjacent to the meristem (centre) 
this to occur. Other mesograzers, especially Panidotea munda, Platynereis sp. and amphipods in the genus Ampithoe, although less abundant than Tethygeneiasp. and Hyale rubra, also may have contributed to this damage. Amphipods and other mesograzers clearly cannot be ignored as potential herbivores of macroalgae, especially if they preferentially feed upon meristematic tissue. Preference for new algal growth by mesograzers has been recorded previously for sphaeromatid isopods feeding on the brown alga Cystoseira baccata (Arrontes 1990), amphipods feeding on the red alga Hypnea spinella (Brawley \& Adey 1981), and for amphipods and idoteid isopods feeding on the red alga Chondrus crispus in algal cultures (Shacklock \& Croft 1981).

Small herbivores inhabiting macroalgae have the opportunity to feed on a variety of epiphytes in addition to their macroalgal host. In contrast to the common preconception (e.g. Bell 1991), Tethygeneia sp. and Hyale rubra did not consistently prefer the common epiphytes of Zonaria angustata ahead of the host plant itself. This preconception has been partly responsible for the neglect of mesograzers in algal ecosystems (Hay et al. 1988b). The predominance of epiphytes in the diets of invertebrate herbivores has also been questioned for the freshwater environment (Lodge 1991). The variety of results in this study indicate that host-epiphyte preferences are probably due to characteristics of the individual epiphyte and host species. The most common small epiphytes of $Z$. angustata in the field were small individuals of relatively large species, and not fast-growing filamentous species as often reported for other systems (e.g. Duffy 1990). It is important to note that the species composition of epiphytes may have been different for plants from which amphipods were excluded.

Two of the commonest epiphytes, Corallina officinalis and encrusting Corallinaceae, were not consumed by the amphipods, presumably due to their high toughness. Coralline algae are eaten by few herbivores (Steneck 1986) and consumption by mesograzers has not been reported. For the 3 epiphytes consumed in the preference experiments, 3 different results were obtained. Zonaria angustata was preferred by both amphipods to the epiphytic Ulva rigida. There is little reason to suggest that $U$. rigida would be unpalatable to herbivores since many studies report the routine consumption of Ulva spp. by amphipods (McGrouther 1983, Buschmann 1990). Agnew \& Moore (1986), however, found that U. lactuca was avoided by the amphipods Echinogammarus pirloti and E. obtusatus. Dean \& Connell (1987) also found that Hyale frequens avoided Ulva spp. in habitat selection experiments despite its suitability as food for the amphipod. Herbivore feeding preferences do not always correlate closely with food quality (Bernays \& Graham 1988).
Pieces of Colpomenia peregrina were preferred by both amphipods to Zonaria angustata but neither were observed to feed upon the intact plant. Providing cut pieces of $C$. peregrina seemed to facilitate amphipod feeding. The amphipods were observed to feed from edges, therefore intact epiphytic C. peregrina, which has a round, globose form, may be an unsuitable shape for amphipod feeding. Plants of $C$. peregrina were often damaged in the field, thus providing edges from which amphipods could feed. If only old plants are damaged, however, herbivory by amphipods may come too late to prevent any detrimental effects of the epiphyte on its host plant. The amphipods displayed no preference between feeding on $Z$. angustata or Chaetomorpha coliformis. Feeding on Chaetomorpha spp. by amphipods has been recorded previously, and there is no reason to suggest $C$. coliformis would be unpalatable to herbivores (McGrouther 1983, Buschmann 1990).

The feeding preference experiments in this study, along with most laboratory-based feeding studies, can only suggest what the animals might eat in the field (Brawley 1992). These experiments had the artefacts of starving amphipods, using only large amphipods, using cut pieces of algae, and not offering the animals the full range of food types encountered in the field. Examination of the gut contents of field-collected amphipods confirmed that they did indeed eat macroalgae, including Zonaria angustata, but could not indicate their feeding preferences.

\section{Within-plant variation and herbivory}

In addition to their abundance and rates of consumption, the way in which mesograzers consume plants is of great importance for predicting their effects on plant fitness. Amphipods did not treat different parts of Zonaria angustata equally due to variation in the physical or chemical nature of tissues within $Z$. angustata.

Differences in toughness between new and old growth near the branch apex could not explain the distinctive pattern of amphipod damage to the apical region of Zonaria angustata. Although the force recorder did not closely mimic the complex feeding action of herbivorous amphipods (McGrouther 1983), it did indicate the relative toughness between new and old growth. A sudden increase in branch toughness would have been required to explain the sharp boundary between the region of new growth eaten and the tissue avoided. Toughness of algal tissue can vary considerably within (Johnson \& Mann 1986) and between species (Steneck \& Watling 1982). Small differences in algal toughness may be important in determining the feeding preferences of mesograzers due to the small 
size of these herbivores. Toughness, however, cannot be separated from chemical properties of the alga and both are likely to act together in determining feeding preferences (Paul \& Hay 1986). Duffy \& Hay (1991b) found that differences in toughness between algal species were unrelated to the feeding preferences of the amphipod Ampithoe longimana.

Consumption of Zonaria angustata by amphipods was negatively correlated with the density of physodes in the tissues close to the branch apex. Phlorotannins present in the physodes of brown algae have been shown to frequently deter herbivores, including amphipods, in temperate North America (Denton \& Chapman 1991, Steinberg 1992). In Australia, however, the role of phlorotannins as defences is less clear, with herbivorous gastropods and urchins largely unaffected by high phlorotannin levels in their diets (Steinberg \& Van Altena 1992). The effects of phlorotannins on mesograzers in Australia, however, has not been investigated.

Although no causal relationship has been demonstrated, the distribution of physodes in the apical region of Zonaria angustata sirongly suggests that the pattern of amphipod feeding is a result of within-plant variation in secondary chemistry. The avoidance of the meristem cells is clearly correlated with physode density. Differences in the nutritional value of the apical tissues, not tested in this study, may be also be important. Despite the problems with quantifying the levels of phlorotannins from physode densities, tissues rich in physodes clearly have higher concentrations than those with few physodes (Ragan \& Glombitza 1986). The acylphloroglucinol derivative found in $Z$. angustata (Blackman et al. 1988) may influence amphipod feeding and be localised in physodes because both this metabolite and phlorotannins are chemically derived from phloroglucinol. In contrast to phlorotannins, little is known about the subcellular localisation of smaller secondary metabolites (Hay \& Fenical 1988).

With the assumptions that plant defences are costly, and that plants will allocate defences to maximise fitness, plant defence theory predicts greater allocation of defences to tissues that are most valuable in terms of plant fitness (Rhoades 1979). Thus, theory predicts highest allocation of defences to meristematic regions, external tissues and reproductive tissues. The high density of physodes in the apical meristem cells of Zonaria angustata supports this prediction. High concentrations of secondary metabolites, relative to the rest of the plant, have also been found in the apical meristems of Neorhodomela larix (Phillips \& Towers 1982), Halimeda spp. (Paul \& Van Alstyne 1988), and Macrocystis angustifolia (Tugwell \& Branch 1989), and in the intercalary meristems of Ecklonia maxima, Lam- inaria pallida (Tugwell \& Branch 1989) and L. longicruris (Johnson \& Mann 1986). High densities of physodes in the apical cells, as observed in $Z$. angus tata, are also present in algae from the order Sphacelariales (Clayton 1990).

Phillips \& Clayton (1991) suggested that phlorotannins in the physodes found in a sterile outer layer of cells in the antheridia of Zonaria angustata may serve to protect these reproductive structures. This view is supported by the observation that the amphipods inhabiting $Z$. angustata sometimes avoid feeding on the single row of apical meristem cells. A single row of physode-rich cells, therefore, has the potential to protect the antheridia from small herbivores. Some mesograzers, including species of Hyale, have been reported to feed preferentially on algal reproductive tissues (Buschmann \& Santelices 1987). In contrast to the allocation of defences to meristems, the allocation to reproductive tissues in algae has not always been consistent with the predictions of defence theory (Steinberg 1992).

Little is known about the within-plant variation of secondary compounds in algae and how it influences feeding by herbivores (Hay \& Steinberg 1992). Too often, algae have been viewed as homogeneous food sources for herbivores (Lubchenco \& Gaines 1981). Consideration of within-plant variation is important for several reasons. Obviously, if the plant is heterogeneous, the choice of plant part used in feeding studies may dramatically influence results. The many chemical studies of the secondary compounds of algae have rarely noted which sections of the plant have been assayed. It is therefore difficult to predict what concentrations of secondary compounds the herbivores naturally encounter. Average concentrations, taken from all tissues combined, are of little use since most herbivores do not eat entire plants. The few studies addressing within-plant variation have used mostly large brown algae and have considered differences between broad tissue types (e.g. Johnson \& Mann 1986, Tugwell \& Branch 1989). At a finer scale, however, Carlson et al. (1989) found considerable variation in the concentrations of 2 bromophenols in the red alga Neorhodomela larix. Bromophenol concentrations often varied by an order of magnitude in adjacent $1 \mathrm{~cm}$ lengths of thallus. Given this variation, ecologists clearly must consider the same divisions between plant parts that the herbivores do (Janzen 1979).

Within-plant variation in secondary chemistry, toughness or value as food is also of ecological significance if it influences the relative susceptibility of different plant parts to herbivores. For example, Johnson \& Mann (1986) showed grazing of the kelp Laminaria longicruris by the gastropod Lacuna vincta to be concentrated on the blade margins which were low in 
phlorotannins and less tough than other regions of the plant. This pattern of damage affected the kelp canopy but did not significantly increase kelp mortality. If grazing was evenly distributed on the plant, the meristem regions (high in phlorotannins) would have been damaged and extensive mortality would have occurred (Johnson \& Mann 1986). Within-plant variation in secondary chemicals, however, will not always correlate with herbivore feeding preferences. Meyer \& Paul (1992) showed that although upright portions of Caulerpa spp. had higher concentrations of the secondary metabolite caulerpenyne than did horizontal portions, the greater concentrations did not deter herbivorous fish.

In Zonaria angustata the within-plant variation in secondary chemistry occurs over a very small spatial scale, just a few millimetres. Such variation can influence the feeding of mesograzers due to their small size and ability to feed selectively at similarly small scales. They may exploit small regions of plant tissue with low levels of secondary chemicals that are unavailable to larger herbivores. Similar selectivity over a small scale has been shown for leaf-galling aphids, which preferentially position their gall in leaf parts low in phenolics (Zucker 1982).

Hay et al. (1987) proposed that mesograzers feeding on algae could be ecologically similar to insects on terrestrial plants in that they live on the plants they eat, are susceptible to high rates of predation, and may reduce this predation by association with chemically defended plants. One similarity, previously ignored, is the way in which these herbivores can exploit their host plants. Their small body size enables selection of plant tissues on a very different scale to that of larger herbivores. Herbivorous mammals may select between leaves on a branch, while small herbivores, such as leaf-mining insect larvae, select between layers of cells within the leaf. This study suggests that small, marine herbivores are able to feed at similar scales, consuming only 1 tissue type and selecting plant parts at almost a cellular level. Given the different value of plant parts to plant fitness, the distribution of herbivore feeding among plant parts is crucial to understanding the effects of herbivores on plants.

Steinberg (1992) has reminded us to heed Janzen's (1979) warning that herbivores eat plant parts, not species and genera. I would add to this the reminder that small herbivores eat even smaller plant parts, and that the interaction between mesograzers and algae must be considered at the small scale of these herbivores. Their importance as herbivores will depend not only on their abundance and feeding preferences between species, but on their selection between tissues within individual plants.
Acknowledgements. This study was undertaken in partial fulfilment of the requirements of Bachelor of Science with Honours at Monash University. I thank Drs Margaret Clayton and Gerry Quinn for their supervision of this project, and for comments on this manuscript. Crustaceans were kindly identified by Dr Gary Poore. I am grateful to Dr John Baldwin, Dr Sam Lake, Dr Julie Phillips, Dr Gordon Sanson, Chris Ashburner, Bruce Fuhrer, Gunta Jaudzems, Nick Crosbie, Ange Hawdon, Roger McKinnon and Martina Doblin for advice and assistance.

\section{LITERATURE CITED}

Agnew, D. J., Moore, P. G. (1986). The feeding ecology of two littoral amphipods (Crustacea), Echinogammarus pirloti (Sexton and Spooner) and E. obtusatus (Dahl). J. exp. mar. Biol. Ecol. 103: 203-215

Arrontes, J. (1990). Diet, food preference and digestive efficiency in intertidal isopods inhabiting macroalgae. J. exp. mar. Biol. Ecol. 139: 231-249

Bell, S. S. (1991). Amphipods as insect equivalents? An alternative view. Ecology 72: 350-354

Bernays, E., Graham, M. (1988). On the evolution of host specificity in phytophagous arthropods. Ecology 69: $886-892$

Blackman, A. J., Rogers, G. I., Volkman, J. K. (1988). Phloroglucinol derivatives from three Australian marine algae of the genus Zonaria. J. nat. Prod. 51: 158-160

Brawley, S. H. (1992). Mesoherbivores. In: John, D. M., Hawkins, S. J., Price, J. H. (eds.) Plant-animal interactions in the marine benthos. Clarendon Press, Oxford, p. $235-263$

Brawley, S. H., Adey, W. H. (1981). The effect of micrograzers on algal community structure in a coral reef microcosm. Mar. Biol. 61: 167-177

Brawley, S. H., Fei, X. G. (1987). Studies of mesoherbivory in aquaria and in an unbarricaded mariculture farm on the Chinese coast. J. Phycol. 23: 613-623

Buschmann, A. H. (1990). Intertidal macroalgae as refuge and food for Amphipoda in Central Chile. Aquat. Bot. 36: $237-245$

Buschmann, A. H., Santelices, B. (1987). Micrograzers and spore release in Iridaea laminarioides Bory (Rhodophyta: Gigartinales). J. exp. mar. Biol. Ecol. 108: 171-179

Carlson, D. J., Lubchenco, J., Sparrow, M. A., Trowbridge, C. D. (1989). Fine-scale variability of lanosol and its disulfate ester in the temperate red alga Neorhodomela larix. J. chem. Ecol. 15: 1321-1333

Clayton, M. N. (1990). Phaeophyta. In: Clayton, M. N., King, R. J. (eds.) Biology of marine plants. Longman Cheshire, Melbourne, p. 149-182

Coen, L. D. (1988). Herbivory by crabs and the control of algal epibionts on Caribbean host corals. Oecologia 75: 198-203

D'Antonio, C. (1985). Epiphytes on the rocky intertidal red alga Rhodomela larix (Turner) $\mathrm{C}$. Agardh: negative effects on the host and food for herbivores? J. exp. mar. Biol. Ecol. 86: $197-218$

Dean, R. L., Connell, J. H. (1987). Marine invertebrates in an algal succession. II. Tests of hypotheses to explain changes in diversity with succession. J. exp. Mar. Biol. Ecol. 109: $217-247$

Denton, A. B., Chapman, A. R. O. (1991). Feeding preferences of gammarid amphipods among four species of Fucus. Mar. Biol. 109: 503-506

Duffy, J. E. (1990). Amphipods on seaweeds: partners or pests? Oecologia 83: $267-276$ 
Duffy, J. E., Hay, M. E. (1991a). Amphipods are not all created equal: a reply to Bell. Ecology 72: $354-358$

Duffy, J. E., Hay, M. E. (1991b). Food and shelter as determinants of food choice by an herbivorous marine amphipod. Ecology 72: 1286-1298

Edgar, G. J. (1983). The ecology of south-eastern Tasmanian phytal animal communities. I. Spatial organisation on a local scale. J. exp. mar. Biol. Ecol. 70: 129-157

Edgar, G. J. (1992). Patterns of colonization of mobile epifauna in a Western Australian seagrass bed. J. exp. mar. Biol. Ecol. 157: 225-246

Fauchald, K., Jumars, P. A. (1979). The diet of worms: a study of polychaete feeding guilds. Oceanogr. mar. Biol. A. Rev. 17: $193-284$

Faulkner, D. J. (1984). Marine natural products: metabolites of marine algae and herbivorous marine molluscs. Nat. Prod. Rep. 1: 251-280

Gerwick, W., Fenical, W. (1982). Phenolic lipids from related marine algae of the order Dictyotales. Phytochemistry 21: $633-637$

Hay, M. E., Duffy, J. E., Fenical, W., Gustafson, K. (1988a). Chemical defense in the seaweed Dictyopteris deliculata: differential effects against reef fishes and amphipods. Mar. Ecol. Prog. Ser. 48: 185-192

Hay, M. E., Duffy, J. E., Pfister, C. A., Fenical, W. (1987). Chemical defense against different marine herbivores: are amphipods insect equivalents? Ecology 68: 1567-1580

Hay, M. E., Fenical, W. (1988). Marine piant-herbivore interactions: the ecology of chemical defense. A. Rev. Ecol. Syst. 19: 111-145

Hay, M. E., Fenical, W. (1992). Chemical mediation of seaweed-herbivore interactions. In: John, D. M. Hawkins, S. J., Price, J. H. (eds.) Plant-animal interactions in the marine benthos. Clarendon Press, Oxford, p. 319-337

Hay, M. E., Renaud, P. E., Fenical, W. (1988b). Large mobile versus small sedentary herbivores and their resistance to seaweed chemical defenses. Oecologia 75: 246-252

Hay, M. E., Steinberg, P. D. (1992). The chemical ecology of plant-herbivore interactions in marine versus terrestrial communities. In: Rosenthal, G. A., Berembaum, M. (eds.) Herbivores: their interaction with secondary plant metabolites, Vol. 2, Ecological and evolutionary processes. Academic Press, San Diego, p. 371-413

Holmlund, M. B., Peterson, C. H., Hay, M. E. (1990). Does algal morphology affect amphipod susceptibility to fish predation? J. exp. mar. Biol. Ecol. 139: 65-83

Janzen, D. H. (1979). New horizons in the biology of plant defenses. In: Rosenthal, G. A., Janzen, D. H. (eds.) Herbivores: their interaction with secondary plant metabolites. Academic Press, New York, p. 331-350

Johnson, C. R., Mann, K. H. (1986). The importance of plant defence abilities to the structure of subtidal seaweed communities: the kelp Laminaria longicruris de la Pylaie survives grazing by the snail Lacuna vincta (Montagu) at high population densities. J. exp. mar. Biol. Ecol. 97 231-267

Lodge, D. M. (1991). Herbivory on freshwater macrophytes Aquat. Bot. 41: 195-224

Lubchenco, J., Gaines, S. D. (1981). A unified approach to marine plant-herbivore interactions I: populations and communities. A. Rev. Ecol. Syst. 12: 405-437

McGrouther, M. A. (1983). Comparison of feeding mechanisms in two intertidal gammarideans, Hyale rupicola (Haswell) and Paracalliope australis (Haswell) (Crustacea: Amphipoda). Aust. J. mar. Freshwat. Res. 34: 717-726

Meyer, K. D., Paul, V. J. (1992). Intraplant variation in secondary metabolite concentration in three species of
Caulerpa (Chlorophyta: Caulerpales) and its effects on herbivorous fish. Mar. Ecol. Prog. Ser. 82: 249-257

Moore, P. G. (1977). Organization in simple communities: observations on the natural history of Hyale nilssoni (Amphipoda) in high littoral seaweeds. In: Keegan, B. F., Céidigh, P. O., Boaden, P. J. S. (eds.) Biology of benthic organisms. 11th European Symposium on Marine Biology. Pergamon Press, Oxford, p. 443-451

Paul, V. J., Hay, M. E. (1986). Seaweed susceptibility to herbivory: chemical and morphological correlates. Mar. Ecol. Prog. Ser. 33: 255-264

Paul, V. J., Van Alstyne, K. L. (1988). Chemical defense and chemical variation in some tropical Pacific species of Halimeda (Halimedaceae: Chlorophyta). Coral Reefs 6: $263-269$

Peterson, C. H., Renaud, P. E. (1989). Analysis of feeding preference experiments. Oecologia 80: 82-86

Phillips, D. W., Towers, G. H. N. (1982). Chemical ecology of red algal bromophenols: I. Temporal, interpopulational and within-thallus measurements of lanosol levels in Rhodomela lanix (Turner) C. Agardh. J. exp. mar. Biol. Ecol. 58: 285-293

Phillips, J. A., Clayton, M. N. (1991). Biflagellate spermatozoids in the Dictyotales: the structure of gametes and gametangia in Zonaria angustata (Dictyotales, Phaeophyta). Phycologia 30: 205-214

Ragan, M. A., Glombitza, K. W. (1986). Phlorotannins, brown algal polyphenols. Prog phycol. Res. 4: 129-241

Rhoades, D. F. (1979). Evolution of plant chemical defense against herbivores, In: Rosenthal, G. A., Janzen, D. H. (eds.) Herbivores: their interaction with secondary plant metabolites. Academic Press, New York., p. 4-54

Robles, C. D., Cubit, J. (1981). Influence of biotic factors in an upper intertidal community: dipteran larvae grazing on algae. Ecology 62: 1536-1547

Sand-Jensen, K. (1977). Effect of epiphytes on eelgrass photosynthesis. Aquat. Bot. 3: 55-63

Shacklock, P. F., Croft, G. B. (1981). Effect of grazers on Chondrus crispus in culture. Aquaculture 22: 331-342

Steinberg, P. D. (1992). Geographical variation in the interaction between marine herbivores and brown algal secondary metabolites. In: Paul, V. J. (ed.) Ecological roles for marine secondary metabolites. Cornell University Press, New York, p. 51-91

Steinberg, P. D., Van Altena, I. (1992). Tolerance of marine invertebrate herbivores to brown algal phlorotannins in temperate Australasia. Ecol. Monogr. 62: 189-222

Steneck, R. S. (1986). The ecology of coralline algal crusts: convergent patterns and adaptive strategies. A. Rev. Ecol. Syst. 17: 273-303

Steneck, R. S., Watling, L. (1982). Feeding capabilities and limitation of herbivorous molluscs: a functional group approach. Mar. Biol. 68: 299-319

Tabachnick, B., Fidell, L. (1989). Using multivariate statistics. Harper \& Row, New York

Tugwell, S., Branch, G. M. (1989). Differential polyphenolic distribution among tissues in the kelps Ecklonia maxima, Laminaria pallida and Macrocystis angustifolia in relation to plant-defence theory. J. exp. mar. Biol. Ecol. 129: $219-230$

Underwood, A. J. (1981). Techniques of analysis of variance in experimental marine biology and ecology. Oceanogr. mar. Biol. A. Rev. 19: 513-605

Wahl, M. (1989). Marine epibiosis. I. Fouling and antifouling: some basic aspects. Mar. Ecol. Prog. Ser. 58: 175-189

Wildish, D. J. (1988). Ecology and natural history of aquatic Talitroidea. Can. J. Zool. 66: 2340-2359 
Wilkinson, L. (1990). SYSTAT: the system for statistics. SYSTAT, Inc., Evanston, IL

Womersley, H. B. S. (1987). The marine benthic flora of southern Australia, Part II. South Australia Government

This article was submitted to the editor
Printing Division, Adelaide

Zucker, W. V. (1982). How aphids choose leaves: the roles of phenolics in host selection by a galling aphid. Ecology 63: $972-981$

Manuscript first received: September 21, 1993

Revised version accepted: January 18, 1994 